\title{
Cancer/Testis Antigen 2 Isoform LAGE-1A
}

National Cancer Institute

\section{Source}

National Cancer Institute. Cancer/Testis Antigen 2 Isoform LAGE-1A. NCI Thesaurus. Code C153125.

Cancer/testis antigen 2 (180 aa, $\sim 18 \mathrm{kDa}$ ) is encoded by the human CTAG2 gene. This protein may play a role in tumorigenesis of several tissues. 